\title{
Tissue oxygen tension during regional low-flow perfusion in neonates
}

\author{
William M. DeCampli, MD, PhD \\ Gregory Schears, $M D^{b}$ \\ Richard Myung, MD \\ Steven Schultz, MD ${ }^{\mathrm{b}}$ \\ Jennifer Creed $^{\mathrm{C}}$ \\ Anna Pastuszko, $\mathrm{PhD}^{\mathrm{c}}$ \\ David F. Wilson, PhD
}

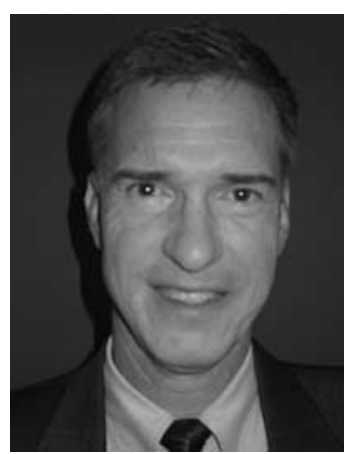

Dr DeCampli

See related editorial on page 456 .

From the Divisions of Pediatric Cardiotho-
racic Surgery ${ }^{\mathrm{a}}$ and Anesthesia and Critical
Care Medicine, ${ }^{\mathrm{b}}$ The Children's Hospital of
Philadelphia, and the Department of Bio-
chemistry and Biophysics, ${ }^{c}$ the University
of Pennsylvania School of Medicine, Phil-
adelphia, Pa.

Supported by provided by divisional funds and by the Healthcare Foundation of New Jersey.

Read at the Eighty-second Annual Meeting of The American Association for Thoracic Surgery, Washington, DC, May 6-8, 2002.

Received for publication May 29, 2002; revisions requested July 8, 2002; revisions received Aug 14, 2002; accepted for publication Sept 13, 2002.

Address for reprints: William M. DeCampli, MD, PhD, Division of Cardiothoracic Surgery, 8th Floor Main, The Children's Hospital of Philadelphia, 34th St and Civic Center Blvd, Philadelphia, PA 19104 (Email: decampli@email.chop.edu).

J Thorac Cardiovasc Surg 2003;125:472-80

Copyright $\odot 2003$ by The American Association for Thoracic Surgery

$0022-5223 / 2003 \$ 30.00+0$

doi: $10.1067 / \mathrm{mtc} .2003 .13$
Objective: We examined cerebral cortical and peripheral organ tissue $\mathrm{Po}_{2}$ values in a neonatal piglet model of regional low-flow perfusion.

Methods: Twenty-one neonatal piglets were placed on cardiopulmonary bypass, were cooled to $18^{\circ} \mathrm{C}$, then underwent either deep hypothermic circulatory arrest or regional low-flow perfusion at 20 or $40 \mathrm{~mL} /(\mathrm{kg} \times \mathrm{min})$ for 90 minutes. Regional low-flow perfusion was carried out by advancing the aortic cannula into the proximal innominate artery. Tissue mean $\mathrm{Po}_{2}$ and $\mathrm{Po}_{2}$ distribution were measured in the cerebral cortex, liver, small bowel, and skeletal muscle through the principle of oxygen-dependent quenching of phosphorescence. Measured quantities were compared by analysis of variance or the Fisher exact test.

Results: During regional low-flow perfusion, axillary and femoral arterial pressures, respectively, were $55 \pm 15$ and $8 \pm 4 \mathrm{~mm} \mathrm{Hg}$ at $40 \mathrm{~mL} /(\mathrm{kg} \times \min )$ and $37 \pm 10$ $\mathrm{mm} \mathrm{Hg}(P=.04)$ and $17 \pm 5 \mathrm{~mm} \mathrm{Hg}(P=.08)$ at $20 \mathrm{~mL} /(\mathrm{kg} \times \min )$. Venous saturations were $95 \% \pm 6 \%$ at $40 \mathrm{~mL} /(\mathrm{kg} \times \mathrm{min})$ and $84 \% \pm 6 \%$ at $20 \mathrm{~mL} /(\mathrm{kg} \times$ $\min )(P=.03$ at 15,30 , and 45 minutes $)$. Cortical $\mathrm{Po}_{2}$ was similar to prebypass values during regional low-flow perfusion at $40 \mathrm{~mL} /(\mathrm{kg} \times \min )(53 \pm 5 \mathrm{~mm} \mathrm{Hg})$ but declined during reperfusion and recovery. Cortical $\mathrm{PO}_{2}$ was lower than before bypass during low-flow perfusion at $20 \mathrm{~mL} /(\mathrm{kg} \times \mathrm{min})(38 \pm 7 \mathrm{~mm} \mathrm{Hg})$ but increased during reperfusion. $\mathrm{PO}_{2}$ in liver and bowel was less than $10 \mathrm{~mm} \mathrm{Hg}$ during low-flow perfusion at both 20 and $40 \mathrm{~mL} /(\mathrm{kg} \times \mathrm{min})$. Fraction of oxygen distribution with $\mathrm{PO}_{2}$ lower than $15 \mathrm{~mm} \mathrm{Hg}$ was less during perfusion at $40 \mathrm{~mL} /(\mathrm{kg} \times$ $\min )$ than at $20 \mathrm{~mL} /(\mathrm{kg} \times \min )(P=.001)$. Three of 6 piglets that received a $40-\mathrm{mL} /(\mathrm{kg} \times \mathrm{min})$ flow rate had significant upper torso edema, metabolic acidosis, and an unstable recovery period, whereas zero of 6 piglets that received a 20-mL/ $(\mathrm{kg} \times \mathrm{min})$ flow rate did.

Conclusions: In a piglet model, regional low-flow perfusion at $20 \mathrm{~mL} /(\mathrm{kg} \times \mathrm{min})$ resulted in lower cortical tissue oxygenation but better recovery than did perfusion at $40 \mathrm{~mL} /(\mathrm{kg} \times \mathrm{min})$. Neither flow rate adequately oxygenated organs in the lower torso.

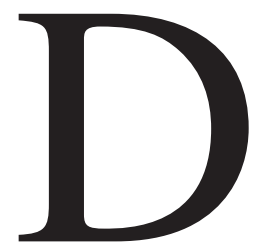

espite remarkable advances in the surgical palliation of complex congenital heart disease, evidence suggests that a substantial fraction of affected patients manifest neurologic and developmental abnormalities. The use of deep hypothermic circulatory arrest (DHCA) may contribute to neurologic injury. This hypothesis has motivated several clinical reports describing an alternative procedure, selective cerebral perfusion or regional low-flow perfusion (RLFP), in which 
the brain is selectively perfused while the remaining organs are maintained, in principle, in a state of DHCA. ${ }^{1-5} \mathrm{Al}-$ though several groups have forged ahead with its clinical application in infants, this technique has not been extensively studied in the laboratory. In this article we present results of our initial study of the characteristics of brain and peripheral organ oxygenation with RLFP.

\section{Methods}

All animals received humane care in compliance with the Guide for the Care and Use of Laboratory Animals prepared by the Institute of Laboratory Animal Resources, National Research Council, and published by the National Academy Press, revised 1996. The experimental protocol was approved by the institutional animal care and use committee at the University of Pennsylvania.

\section{Animal Preparation}

Twenty-one neonatal piglets (weight $1.8-3.0 \mathrm{~kg}$, age 2-4 days) were randomly assigned to one of three groups: DHCA, 90 minutes of DHCA ( $\mathrm{n}=7$ ); RLFP 20, 90 minutes of RLFP at 20 $\mathrm{mL} /(\mathrm{kg} \times \min )(\mathrm{n}=7)$; or RLFP 40,90 minutes of RLFP at 40 $\mathrm{mL} /(\mathrm{kg} \times \min )(\mathrm{n}=7)$. With the animal under fentanyl and halothane anesthesia, 7- to 10-mm burr holes were created in the left and right temporoparietal areas. A 1-cm incision was made over the left foreleg to expose underlying muscle. Anesthesia was maintained with fentanyl and isoflurane. A median sternotomy was performed, and the incision was extended to the umbilicus. The aortic arch vessels were encircled with tourniquets. The ductus arteriosus was ligated. Cardiopulmonary bypass (CPB) was begun with an ascending aortic cannula and single right atrial cannula. After 20 minutes of cooling to $18^{\circ} \mathrm{C}$ (nasopharyngeal), the aorta was occluded, the heart was arrested, and the pump flow was then shut off. The animal then underwent either DHCA or RLFP according to the following protocol. After 90 minutes the aortic clamp was removed, and global CPB was reinstituted with warming to $37^{\circ} \mathrm{C}$ over 20 to 30 minutes. At $37^{\circ} \mathrm{C} \mathrm{CPB}$ was discontinued. Inotropic or vasoactive drugs were not used. Heterologous blood was transfused to maintain adequate preload and keep the hemoglobin at greater than $10 \mathrm{mg} / \mathrm{dL}$. Sodium bicarbonate was used to correct metabolic acidosis. The piglet was decannulated, and the wounds were reapproximated to minimize heat loss. Four hours after CPB the animal was killed with potassium chloride.

\section{Perfusion Technique}

A roller pump (COBE Cardiovascular, Inc, Arvada, Colo), membrane oxygenator (Lilliput I; COBE Cardiovascular), and 50- $\mu \mathrm{m}$ arterial filters (Capiox; Terumo Cardiovascular Systems, Corp, Ann Arbor, Mich) were used. The pump was primed initially with a balanced saline solution $(400 \mathrm{~mL})$ and then with fresh-frozen plasma $(50 \mathrm{~mL})$ and packed red blood cells $(300 \mathrm{~mL})$. Methylprednisolone at $30 \mathrm{mg} / \mathrm{kg}$ was used. Heparin was given to maintain the activated clotting time longer than 400 seconds. Initial flow rate was $150 \mathrm{~mL} /(\mathrm{kg} \times \min )$. Blood was added to keep hematocrit between $23 \%$ and $26 \%$ throughout CPB. Alpha-stat protocol was used for blood gas management. Cardioplegia consisted of the modified Krebs solution (induction $25 \mathrm{~mL} / \mathrm{kg}$, maintenance 10 $\mathrm{mg} / \mathrm{kg}$ ). Modified ultrafiltration was not used.

\section{RLFP}

After discontinuation of CPB flow and administration of cardioplegia, the left subclavian artery was occluded with a tourniquet. The aortic cannula was then advanced into the innominate artery, and a tourniquet was placed proximal to all three branches (right subclavian artery and both carotid arteries). Flow was then established at either 20 or $40 \mathrm{~mL} /(\mathrm{kg} \times \mathrm{min})$ according to the same protocols as described previously for global CPB. In the piglet, the innominate artery gives rise to the right subclavian artery and both carotid arteries. The position of the tip of the cannula proximal to the origin of these three vessels was confirmed by direct palpation and by the pressure in all three vessels. Thus all three vessels were perfused. At the end of RLFP (90 minutes), the tourniquets were released, and the cannula was pulled back into the ascending aorta for continuation of $\mathrm{CPB}$.

\section{Tissue Oximetry}

Tissue $\mathrm{PO}_{2}$ was determined according to the principle of oxygendependent quenching of phosphorescence. ${ }^{6-8}$ Briefly, a phosphorescent probe (Oxyphor G2; Oxygen Enterprises, Ltd, Philadelphia, Pa) was administered intravenously (dose $4 \mathrm{mg} / \mathrm{kg}$ ). After near-infrared excitation, the probe either emitted light or transferred the energy to molecular oxygen (quenching). The observed radiative lifetime was thus shortened by the degree of quenching. In the diffusion limit this lifetime, $t$, was given by the SternVolmer equation:

$$
1 / \mathrm{t}=1 / \mathrm{t}_{\mathrm{o}}+\mathrm{k}_{\mathrm{q}}[\mathrm{Q}]
$$

where $t_{o}$ is the characteristic lifetime of radiative decay, $k_{q}$ is the second order rate constant for quenching (related to the frequency of collision between the probe and quenching molecule), and [Q] is the oxygen concentration, which can then be solved for.

Single-frequency phosphorimetry. Average tissue $\mathrm{PO}_{2}$ for a given volume sampled was measured with a frequency domain phosphorimeter (PMOD 2000; Oxygen Enterprises; Figure 1). Sinusoidally modulated excitation light $(635 \mathrm{~nm})$ was transmitted to the tissue through one branch of a bifurcated fiber-optic light guide and illuminated an approximately 4-mm diameter surface area of tissue. The light guide and detector were hand held 1 to 2 $\mathrm{mm}$ above the surface of the tissue. As best as possible the tissue surface was kept free of pooled blood according to direct inspection. The same bifurcated guide was used for all organ tissue measurements. Detector baseline was determined before the first measurement and was not affected by moving the probe among organs. Phosphorescence $(800 \mathrm{~nm})$ was returned through the second branch of the light guide, passed through a 635-nm filter, and measured. Phosphorescence lifetime was determined from the phase relationship relative to the excitation light; the free oxygen concentration was then calculated as described previously. Single measurement acquisition time was 10 to 20 seconds. Stability of the measurement was established by averaging two or more signal acquisitions, ignoring acquisitions departing widely from the mean. The method has been validated against $\mathrm{Po}_{2}$ measured by microelectrode in vitro $^{9}$ and in tissue..$^{10,11}$

Multifrequency phosphorimetry. Vinogradov and Wilson ${ }^{12,13}$ developed algorithms for determining the distribution of phosphorescence lifetimes in tissue with heterogeneous quencher (oxygen) concentration. Briefly, excitation light $(635 \mathrm{~nm})$ modulated at 200 


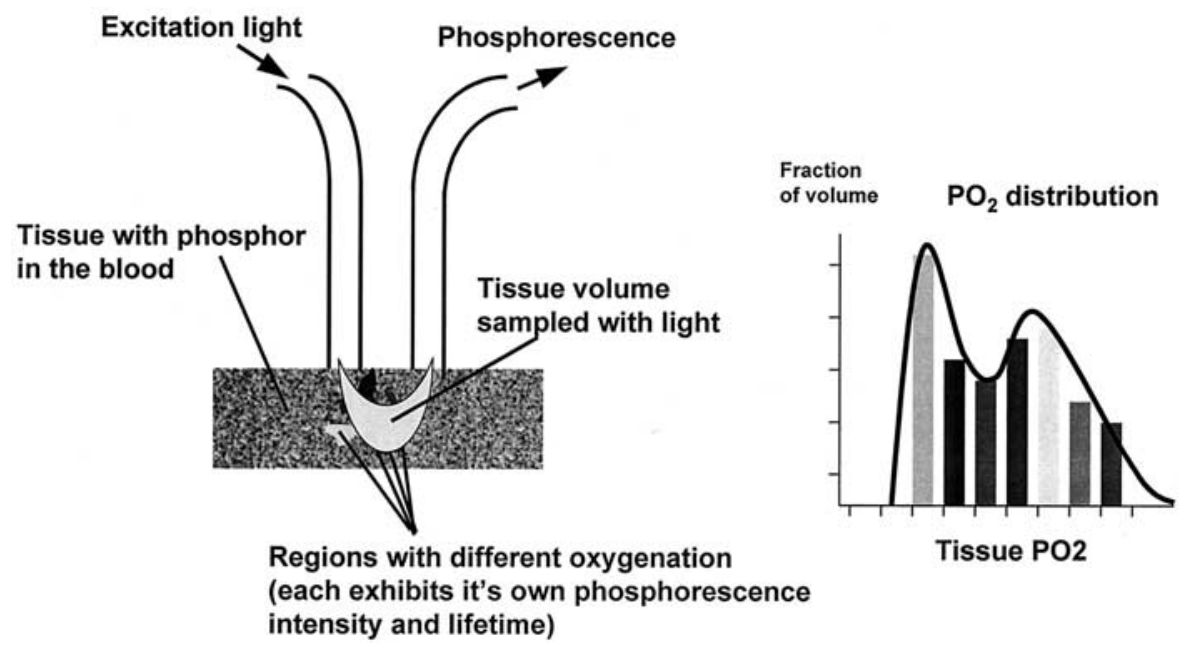

Figure 1. Frequency-domain oxygen phosphorimetry. See text for description.

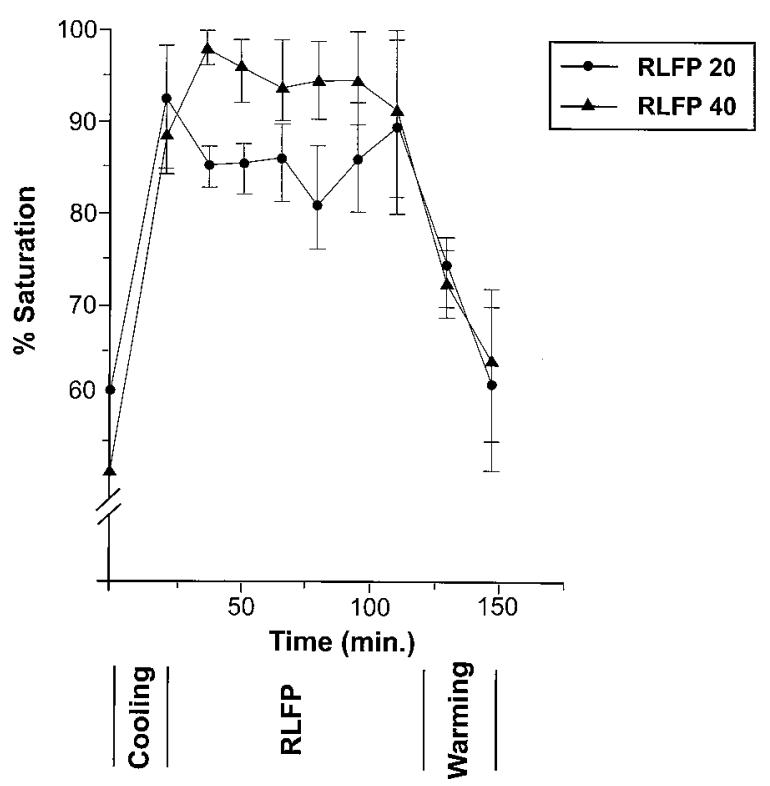

Figure 2. $\mathrm{SvO}_{2}$ values for RLFP 20 (circles) and RLFP 40 (triangles) groups.

simultaneous frequencies (equally spaced between $100 \mathrm{~Hz}$ and 20 $\mathrm{kHz}$ ) was transmitted to tissue by a light guide. A second light guide spaced $8 \mathrm{~mm}$ from the incident guide received the phosphorescence $(800 \mathrm{~nm})$. The depth of tissue sampled was approximately $6 \mathrm{~mm}$. The phase and amplitude of the phosphorescence were determined for each frequency, and the distribution of phosphorescence lifetimes was then computed and converted to a histogram of molecular $\mathrm{Po}_{2}$. The technique allowed estimation of the fraction of tissue volume with hypoxic levels of $\mathrm{Po}_{2}$.

\section{Measurement Protocol}

Single-frequency and multifrequency measurements of tissue $\mathrm{PO}_{2}$ of both frontoparietal areas of the cerebral cortex, left foreleg skeletal muscle, liver, and small intestine were made at 15-minute intervals during each phase of the experiment. Pressure was continuously monitored in the right femoral artery $\left(\mathrm{P}_{\text {fem }}\right)$, and axillary $\left(\mathrm{P}_{\mathrm{ax}}\right)$ artery, and right atrium. During RLFP the total vascular resistance index was calculated as $\left[\mathrm{P}_{\mathrm{ax}}-\mathrm{RAP}\right] \times \mathrm{wt} / \mathrm{Q}$, where $R A P$ was right atrial pressure, $Q$ was the flow rate of RLFP, and $w t$ was the body weight in kilograms.

\section{Statistical Methods}

One-way or repeated measures analysis of variance was used to determine presence of significant differences among the three groups. Student $t$ tests with Bonferroni correction were then performed to quantify these differences. The Fisher Exact test was used when the number of samples was less than 6. Results are expressed as mean $\pm \mathrm{SD}$.

\section{Results}

Three animals could not be weaned from bypass, either for technical reasons or reasons related to myocardial protection, and were excluded from the analysis. The remaining cohort consisted of 18 animals, 6 in each group. Weights were $2.5 \pm 0.4,2.5 \pm 0.36$, and $2.3 \pm 0.3 \mathrm{~kg}$ (differences not significant) in the DHCA, RLFP 20, and RLFP 40 groups, respectively.

\section{Blood Gas Data}

Table 1 shows arterial blood gas analyses for the various stages of the protocol. Values are corrected to the animal's temperature at the time of measurement. $\mathrm{PCO}_{2}$ decreased significantly during selective perfusion in the RLFP 20 and RLFP 40 groups because of the alpha-stat protocol $(P<$ .001). Serum bicarbonate was significantly lower in the RLFP 20 group than in the RLFP 40 group during cooling, the first 15 minutes of RLFP, at 90 minutes of RLFP, and again during early reperfusion $(P=.002, P=.001, P=$ .02 , and $P=.0004$, respectively), with a trend toward being 
TABLE 1. Arterial blood gas analysis for the various stages of the protocol, corrected to animal temperature at the time of measurement

\begin{tabular}{|c|c|c|c|c|c|}
\hline & Before bypass & Cooling & RLFP or DHCA & Rewarming & Recovery \\
\hline \multicolumn{6}{|l|}{$\mathrm{pH}$} \\
\hline DHCA & $7.41 \pm 0.08$ & $7.56 \pm 0.09$ & - & $7.39 \pm 0.06$ & $7.43 \pm 0.06$ \\
\hline RLFP 20 & $7.41 \pm 0.11$ & $7.53 \pm 0.18$ & $7.67 \pm 0.08$ & $7.41 \pm 0.14$ & $7.34 \pm 0.09$ \\
\hline RLFP 40 & $7.43 \pm 0.09$ & $7.65 \pm 0.10$ & $7.76 \pm 0.01$ & $7.41 \pm 0.07$ & $7.44 \pm 0.03$ \\
\hline \multicolumn{6}{|c|}{$\mathrm{Po}_{2}(\mathrm{~mm} \mathrm{Hg})$} \\
\hline DHCA & $165.3 \pm 68.38$ & $244.8 \pm 66.34$ & - & $169.2 \pm 37.76$ & $119.2 \pm 50.07$ \\
\hline RLFP 20 & $124.7 \pm 35.41$ & $200.3 \pm 67.75$ & $193.5 \pm 13.53$ & $143.8 \pm 63.40$ & $166.2 \pm 59.50$ \\
\hline RLFP 40 & $139.7 \pm 21.60$ & $222.1 \pm 49.77$ & $194.5 \pm 18.58$ & $120.7 \pm 25.04$ & $171.2 \pm 37.36$ \\
\hline \multicolumn{6}{|c|}{$\mathrm{PcO}_{2}(\mathrm{~mm} \mathrm{Hg})$} \\
\hline DHCA & $40.9 \pm 4.20$ & $24.3 \pm 5.87$ & - & $34.5 \pm 4.08$ & $31.9 \pm 7.57$ \\
\hline RLFP 20 & $36.7 \pm 9.73$ & $20.0 \pm 10.32$ & $13.4 \pm 1.86$ & $31.9 \pm 14.2$ & $36.3 \pm 6.62$ \\
\hline RLFP 40 & $35.8 \pm 7.22$ & $20.3 \pm 4.31$ & $15.5 \pm 2.72$ & $31.0 \pm 0.90$ & $32.5 \pm 3.55$ \\
\hline \multicolumn{6}{|c|}{ Bicarbonate $(\mathrm{mEg} / \mathrm{L})$} \\
\hline DHCA & $25.7 \pm 4.89$ & $24.5 \pm 3.02$ & - & $20.8 \pm 1.73$ & $20.8 \pm 2.83$ \\
\hline RLFP 20 & $22.1 \pm 2.91$ & $17.8 \pm 3.51$ & $16.54 \pm 1.55$ & $17.8 \pm 4.09$ & $18.9 \pm 2.99$ \\
\hline RLFP 40 & $23.8 \pm 1.71$ & $25.7 \pm 2.75$ & $23.59 \pm 2.68$ & $19.9 \pm 3.09$ & $22.4 \pm 3.14$ \\
\hline \multicolumn{6}{|c|}{ Hemoglobin (mq \%) } \\
\hline DHCA & $6.6 \pm 1.06$ & $6.9 \pm 1.19$ & - & $7.6 \pm 1.19$ & $10.8 \pm 0.09$ \\
\hline RLFP 20 & $8.6 \pm 2.56$ & $7.3 \pm 1.14$ & $7.6 \pm 0.26$ & $7.6 \pm 0.94$ & $11.7 \pm 2.03$ \\
\hline RLFP 40 & $9.7 \pm 1.98$ & $8.3 \pm 1.38$ & $7.6 \pm 0.33$ & $7.3 \pm 0.62$ & $9.5 \pm 3.41$ \\
\hline
\end{tabular}

lower throughout RLFP. Hemoglobin was $7.5 \pm 0.5 \mathrm{mg} / \mathrm{dL}$ during RLFP (not significantly different among groups) and was increased (per protocol) significantly to $10.6 \pm 0.3$ $\mathrm{mg} / \mathrm{dL}$ by transfusion after weaning from CPB.

Figure 2 shows the venous saturation $\left(\mathrm{SvO}_{2}\right)$ data. Within groups there was no significant trend in $\mathrm{SvO}_{2}$ with time during RLFP (by repeated measures analysis of variance). $\mathrm{SvO}_{2}$ was significantly greater in the RLFP 40 group than in the RLFP 20 group at 15,30 , and 45 minutes into RLFP $(P=.001, P=.03$, and $P=.03$, respectively). Oxygen extraction averaged $0.30 \pm 0.1 \mathrm{~mL} /(\mathrm{kg} \times \mathrm{min})$ during RLFP and showed no significant time evolution or difference between RLFP groups.

\section{Clinical and Hemodynamic Data}

Although both RLFP groups required administration of fluid and sodium bicarbonate to support blood pressure and treat metabolic acidosis after CPB, the RLFP 40 group required more than twice the amount of bicarbonate and saline solution as did the RLFP 20 group $(P=.02)$. Three of 6 animals in the RLFP 40 group recovered particularly poorly, demonstrating qualitatively more head and upper torso edema than seen in any subjects in the RLFP 20 group. Figure 3, $A$ and $B$, shows $\mathrm{P}_{\mathrm{ax}}$ and $\mathrm{P}_{\text {fem }}$ during RLFP. There was no significant time evolution through the duration of RLFP. $P_{a x}$ values were significantly greater in the RLFP 40 group than in the RLFP 20 group at $30,45,60$, and 90 minutes $(P=.03, P=.05, P=.03$, and $P=.04$, respectively) but tended to be less than in the RLFP 20 group during reperfusion and the early post-CPB period. Conversely, $\mathrm{P}_{\text {fem }}$ tended to be lower in the RLFP 40 group than in the RLFP 20 group. Interestingly, the variation in $\mathrm{P}_{\mathrm{ax}}$ during RLFP among animals was much greater in the RLFP 40 group than in the RLFP 20 group. Much of the variation was due to rather high $P_{a x}$ in the 3 animals in the RLFP 40 group that had poor recovery after CPB. During RLFP the total vascular resistance index averaged $1.86 \pm$ $0.4 \mathrm{~mm} \mathrm{Hg} \times \mathrm{kg} /(\mathrm{mL} \times \mathrm{min})$ in the RLFP 20 group and $1.46 \pm 0.35 \mathrm{~mm} \mathrm{Hg} \times \mathrm{kg} /(\mathrm{mL} \times \mathrm{min})$ in the RLFP 40 group $(P=.002)$.

\section{Cortical Oxygen Data}

Figure 4 displays the single-frequency phosphorimetric cortical (brain) $\mathrm{Po}_{2}$ measured in the left temporoparietal area. $\mathrm{PO}_{2}$ was significantly lower throughout RLFP or DHCA than pre-CPB values in both the RLFP $20(P=.01)$ and DHCA $(P=.001)$ groups. $\mathrm{PO}_{2}$ in the RLFP 40 group, however, was comparable to pre-CPB values during RLFP. Thus only RLFP 40 preserved cortical $\mathrm{PO}_{2}$ during the period of selective perfusion. With reperfusion and warming, cortical $\mathrm{PO}_{2}$ remained lower than pre-CPB values in the DHCA group $(P=.01)$, whereas $\mathrm{PO}_{2}$ values were not significantly different from their respective pre-CPB values in both RLFP groups. Thus RLFP groups recovered cortical $\mathrm{Po}_{2}$ to pre-CPB values during early reperfusion and warming. In late recovery (2-4 hours after $\mathrm{CPB}), \mathrm{PO}_{2}$ in the DHCA group was still depressed below baseline $(P=.001)$, whereas $\mathrm{PO}_{2}$ was still comparable to baseline in the RLFP 20 group. In the RLFP 40 group, however, $\mathrm{Po}_{2}$ declined and was significantly lower than pre-CPB baseline $(P=.01)$. This decline may in part be related to the poorer clinical status of several of the subjects in the RLFP 40 group alluded to previously. 

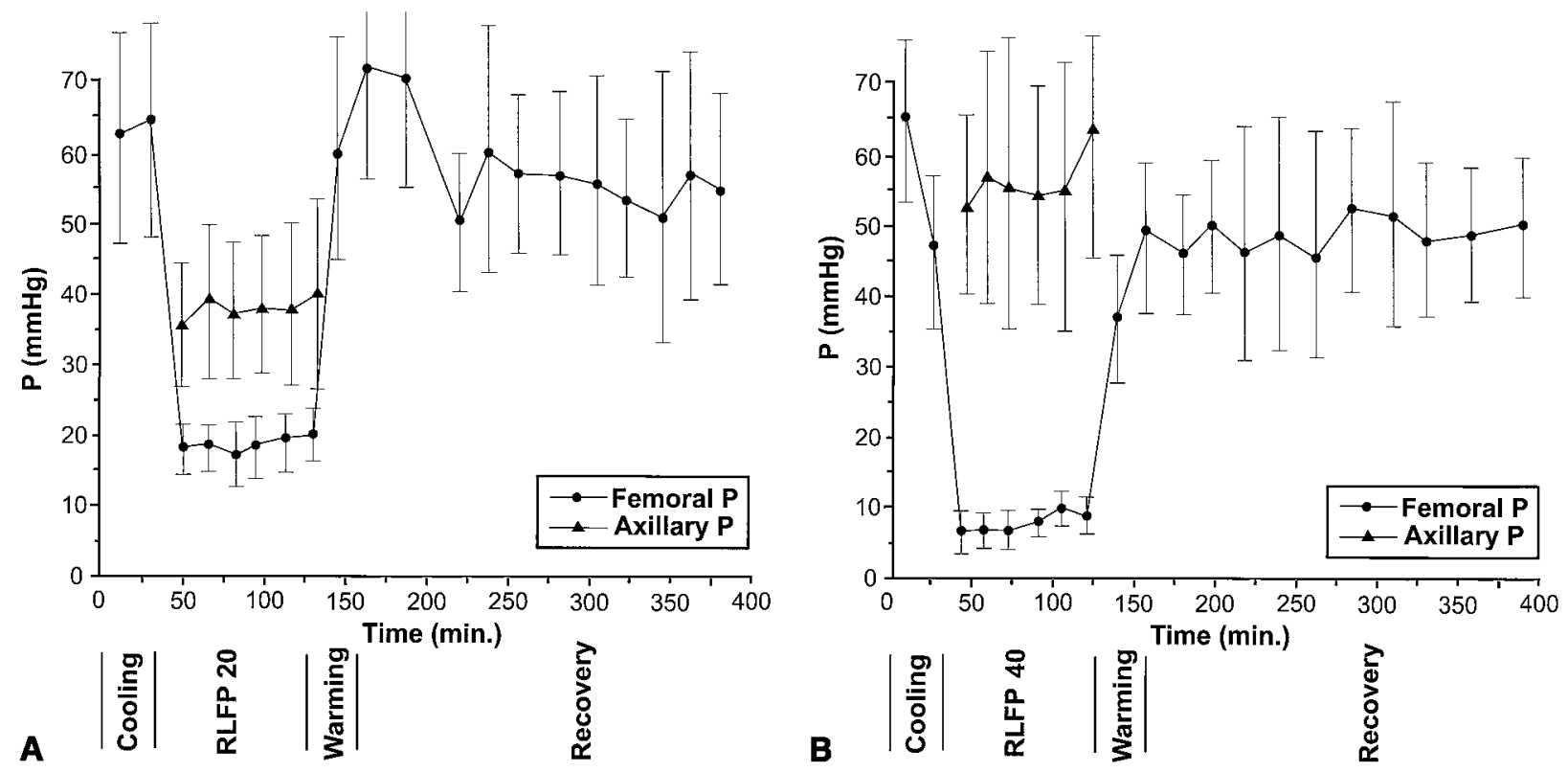

Figure 3. $A, P_{a x}$ (triangles) and $P_{\text {fem }}$ (circles) for RLFP 20 group. $B, P_{a x}$ (triangles) and $P_{\text {fem }}$ (circles) for RLFP 40 group.

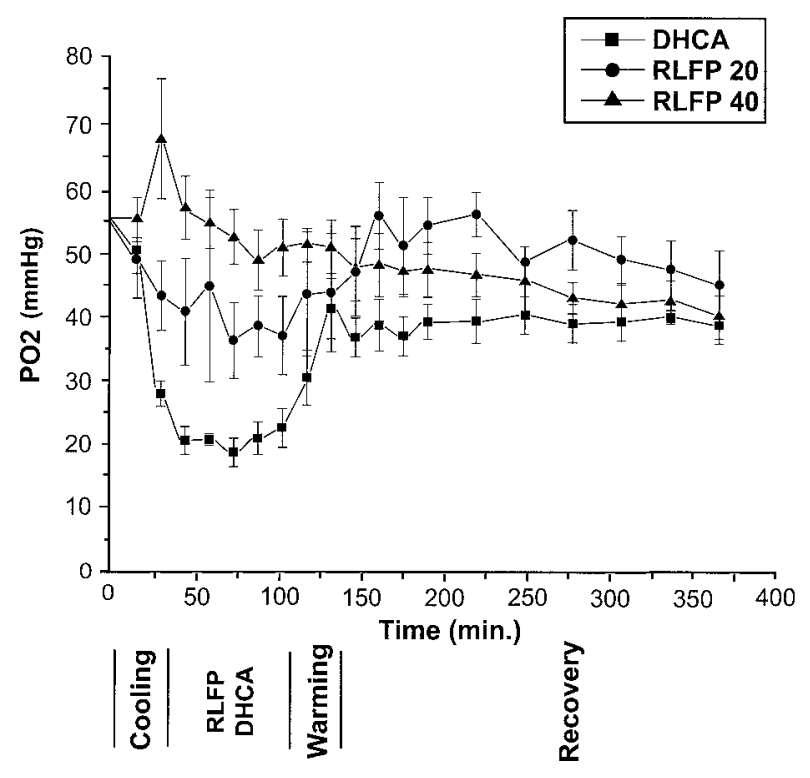

Figure 4. Mean absolute $\mathrm{Po}_{2}$ in millimeters of mercury in left temporoparietal cortex versus phase of experimental protocol for DHCA (squares), RLFP 20 (circles), and RLFP 40 (triangles) groups. Each large tick mark on abscissa represents 50 minutes of time.

Figure 5 demonstrates that values of cortical $\mathrm{Po}_{2}$ (RLFP 40 group) were not significantly different for the left and right sides of the brain.

Figure 6 shows stacked representative $\mathrm{Po}_{2}$ histograms of the multifrequency phosphorimetric measurements from a subject in the RLFP 20 group. The data typically showed a

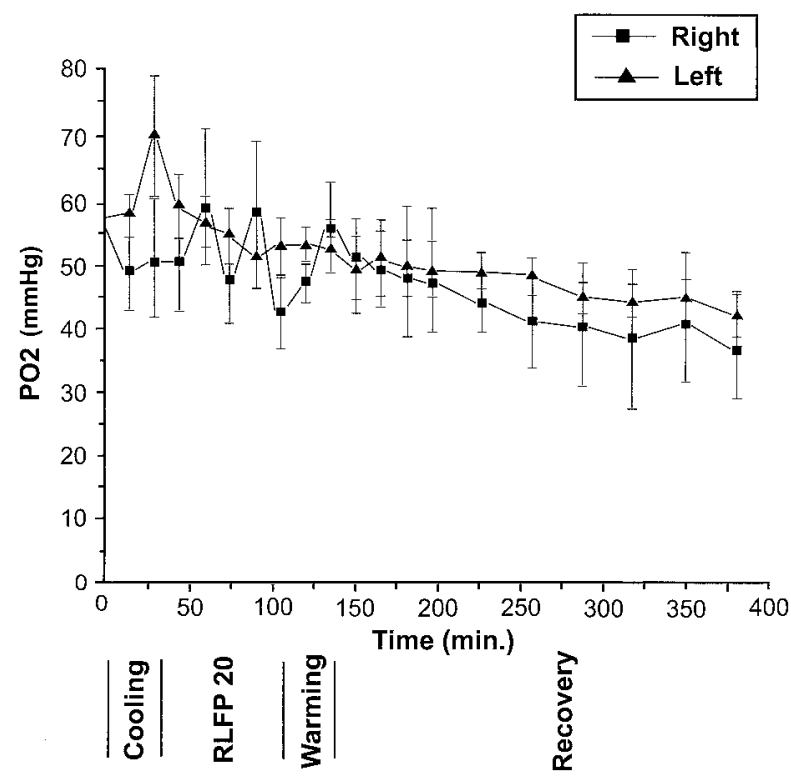

Figure 5. Mean absolute $\mathrm{Po}_{2}$ in millimeters of mercury of left (triangles) and right (circles) temporoparietal areas for RLFP 40 group.

single peak centered on a normal $\mathrm{Po}_{2}$ pre-CPB. During RLFP, a secondary peak developed, centered on a low $\mathrm{PO}_{2}$ and indicating regions of tissue in which $\mathrm{PO}_{2}$ was low. During reperfusion this low $\mathrm{Po}_{2}$ peak decreased but did not completely vanish. Figure 7 shows a plot of the fractional area under that part of the histogram curves bounded by $\mathrm{PO}_{2}$ 


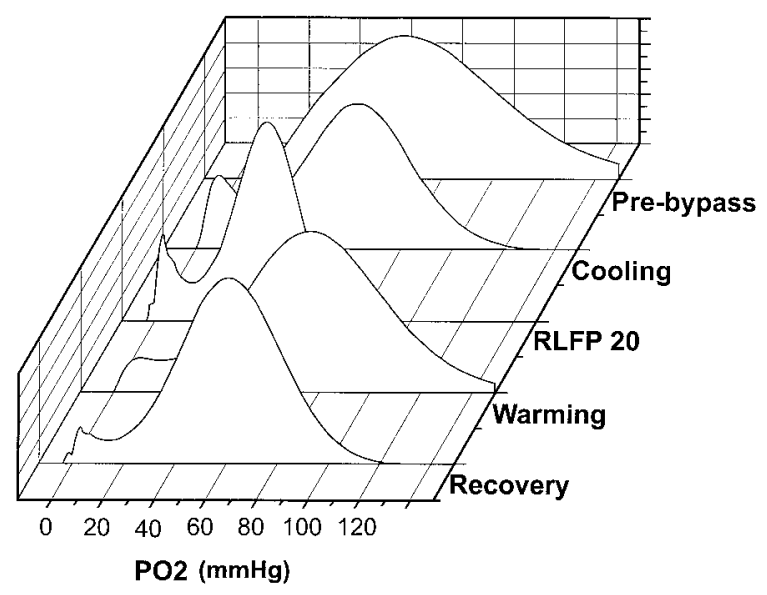

Figure 6. Representative $\mathrm{Po}_{2}$ distribution in region of left temporoparietal cortex of subject in RLFP 20 group. X-axis is pressure in millimeters of mercury, $y$-axis is phase of experimental protocol, and z-axis is phosphorimetric signal intensity larbitrary units).

less than $15 \mathrm{~mm} \mathrm{Hg}$. Qualitatively, this calculated value was proportional to the fraction of tissue volume in the sample that was hypoxic. The figure demonstrates the fraction of hypoxic tissue during RLFP was significantly less in the RLFP 40 than in the RLFP 20 group $(P=.001)$. A significant difference persisted for 20 to 30 minutes of the reperfusion period.

\section{Peripheral Organ Oxygen Data}

Figure $8, A, B$, and $C$, shows single-frequency phosphorimetric $\mathrm{PO}_{2}$ data for the liver, small intestine, and left foreleg muscle, respectively. In organs in the lower torso, the tissue $\mathrm{PO}_{2}$ was very low $(<8 \mathrm{~mm} \mathrm{Hg})$ throughout DHCA and RLFP, indicating that, at least in the porcine model, the peripheral organs are poorly perfused even at relatively high-flow RLFP. Somewhat greater pressures (10-25 mm $\mathrm{Hg}$ ) were observed in the skeletal muscle in the RLFP 40 group, perhaps because of better collateral flow to this upper torso extremity. During reperfusion and after $\mathrm{CPB}$, the intestinal tissue attained $\mathrm{PO}_{2}$ values not significantly different from pre-CPB values $(P=.2)$ in the RLFP 20 group but significantly lower than pre-CPB values in the other two groups $(P=.0004)$. During reperfusion and the early post$\mathrm{CPB}$ period, muscle $\mathrm{PO}_{2}$ was significantly greater in the RLFP 20 group than in the other two groups at 30 minutes of reperfusion and at 45 and 60 minutes after CPB. Histogram data of peripheral organs, like those of the cerebral cortex, showed that the local peak in the signal at low $\mathrm{PO}_{2}$ $(<15 \mathrm{~mm} \mathrm{Hg})$ persisted well into reperfusion, indicating that some regions of tissue continued to be hypoxic.

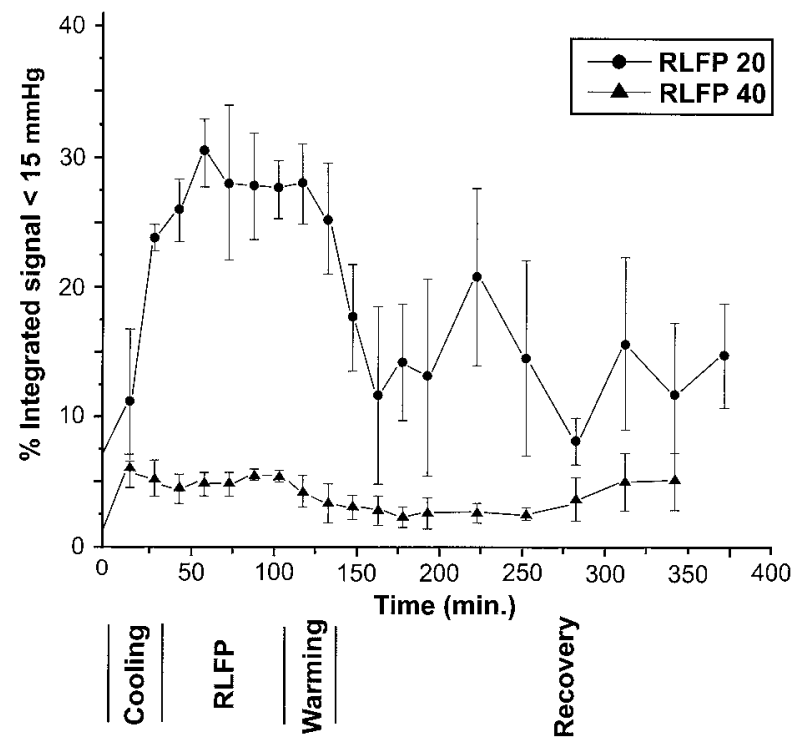

Figure 7. Percentage of integrated phosphorimetric signal intensity below $15 \mathrm{~mm} \mathrm{Hg}$ in the temporoparietal cortex for RLFP 20 (circles) and RLFP 40 (triangles) groups.

\section{Discussion}

RLFP has been used for more than a decade in congenital cardiac surgery in an attempt to reduce central nervous system injury during the operative phase that would otherwise be conducted under DHCA. ${ }^{1-3,5}$ The physiology and the neurodevelopmental impact of the technique, however, have not been studied. This study represents the first systematic approach to understanding the physiology of RLFP in neonates by using a porcine model that mimics the actual operative technique for arch reconstruction.

Our data are consistent with the hypothesis that tissue $\mathrm{PO}_{2}$ was greater during higher flow RLFP (RLFP 40) but that this flow rate was excessive, in that it was associated with upper torso edema, greater post-CPB acidosis, and an overall declining clinical course after CPB. Although we did not prove so, we conjecture that this flow caused cerebral edema and perhaps cerebral vascular injury, resulting in central nervous system instability after $\mathrm{CPB}$, which in turn contributed to the clinical deterioration. This phenomenon has been observed previously. Watanabe and colleagues, ${ }^{14}$ for example, demonstrated increased cerebral ratio of glucose to oxygen metabolism and progressive vasoconstriction with a global CPB flow of $100 \mathrm{~mL} /(\mathrm{kg} \times \mathrm{min})$ at $20^{\circ} \mathrm{C}$ in a canine model.

By contrast, RLFP at $20 \mathrm{~mL} /(\mathrm{kg} \times \min )$ resulted in a lesser cortical $\mathrm{PO}_{2}$ and a relatively greater proportion of hypoxic tissue, but overall recovery was better. This flow rate is similar to the average value used by Pigula and associates ${ }^{15}$ in 6 neonates, all of whom had good short-term neurologic and overall clinical recoveries. Even lower acceptable limits of cerebral blood flow at $20^{\circ} \mathrm{C}$ have been 

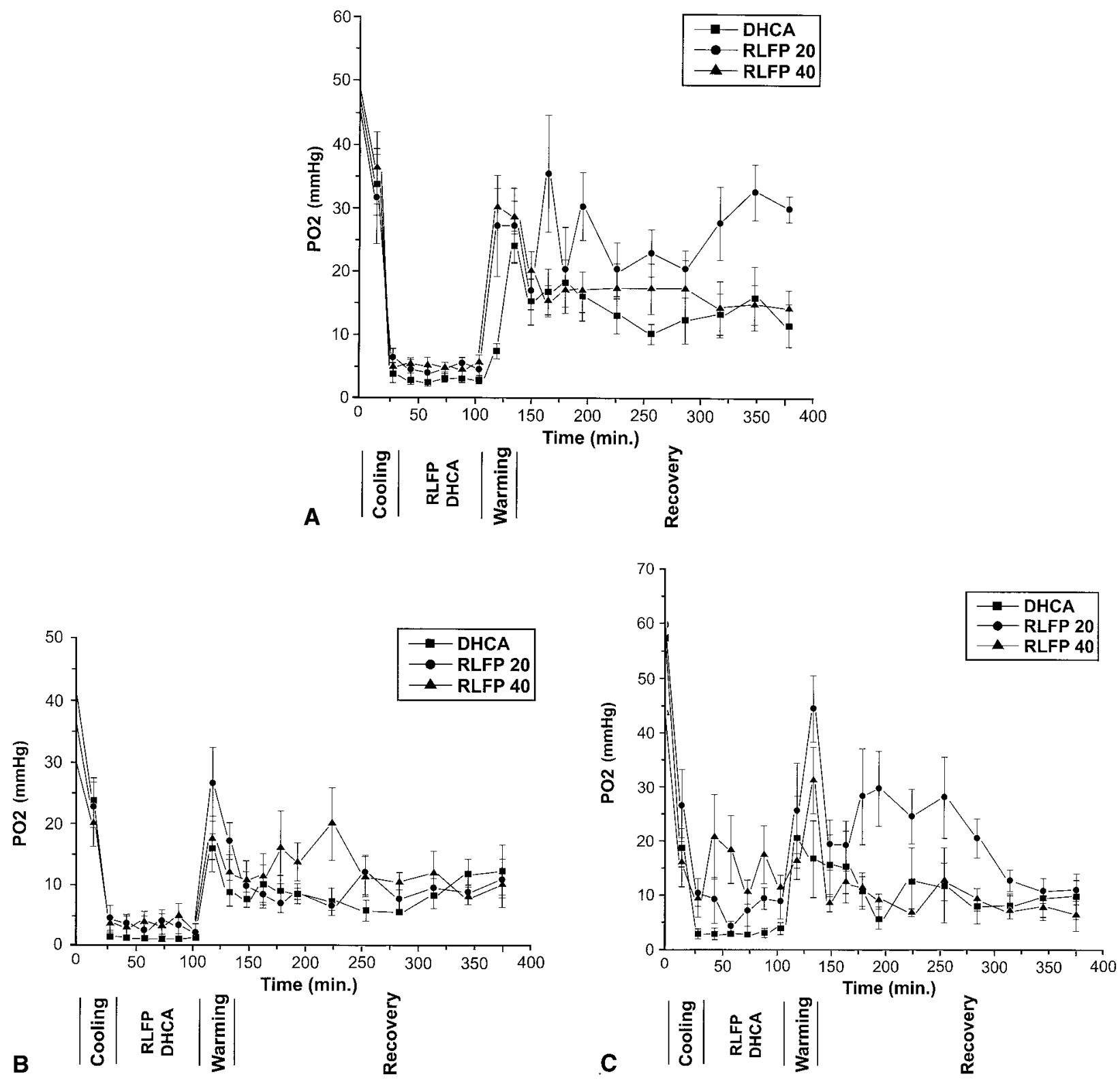

Figure 8. Mean absolute $\mathrm{P}_{2}$ values in millimeters of mercury versus phase of experimental protocol for DHCA (squares), RLFP 20 (circles), and RLFP 40 (triangles) groups. A, Small bowel. B, Liver. C, Left upper extremity skeletal muscle.

reported. ${ }^{14,16-18}$ Despite the results of these studies, however, we consistently found areas of hypoxia during RLFP at $20 \mathrm{~mL} /(\mathrm{kg} \times \mathrm{min})$ in our neonatal model. In our DHCA group, cortical $\mathrm{Po}_{2}$ remained depressed after $\mathrm{CPB}$ relative to its pre-CPB value, consistent with a previous study in our laboratory as well as others, showing depressed cerebral perfusion and oxygen metabolism after DHCA. ${ }^{19-23}$

In this study $\mathrm{P}_{\text {fem }}$ during RLFP was low $(8-18 \mathrm{~mm} \mathrm{Hg}$ ), as was tissue $\mathrm{PO}_{2}$ in the liver and intestine $(0-10 \mathrm{~mm} \mathrm{Hg})$. These observations suggest that neither RLFP flow rate adequately oxygenated organs in the lower torso. By contrast, Pigula and associates ${ }^{15}$ found that quadriceps relative blood volume, relative $\mathrm{So}_{2}$ (by near-infrared spectrophotometry), and the arterial-gastric mucosal $\mathrm{PCO}_{2}$ gradient were preserved during RLFP at 20 to $30 \mathrm{~mL} /(\mathrm{kg} \times \mathrm{min})$ in 15 neonates undergoing aortic arch reconstruction. ${ }^{24} \mathrm{Al}-$ though the contrasting results may represent interspecies differences, we would advise caution in assuming that the lower organs are adequately perfused during RLFP until more direct measures of tissue oxygenation can be made. 
The alpha-stat blood gas strategy was employed during cooling, during RLFP (or DHCA), and during rewarming in this study. That is, $\mathrm{PCO}_{2}$, as measured at a blood temperature of $37^{\circ} \mathrm{C}$, was kept as close as possible to $40 \mathrm{~mm} \mathrm{Hg}$. We chose this strategy to mimic the strategy used in the recent clinical series of RLFP during aortic arch reconstruction. ${ }^{4,15,22}$ With the $\mathrm{pH}$-stat strategy during cooling, cerebral blood flow is greater, oxygen-hemoglobin dissociation is greater, oxygen demand is decreased, cooling is more homogeneous, and overall neurologic protection may be improved relative to the alpha-stat strategy. ${ }^{25-29}$ The superiority of one strategy to the other with RLFP remains unclear. Likewise, the effect of $\alpha$-receptor blockade during RLFP is unknown. Both effects require investigation.

In this study we made direct measurements of absolute tissue (microvascular) $\mathrm{Po}_{2}$. This variable should be a good marker for adequacy of tissue oxygenation, because oxygen diffusion from the microvasculature to the mitochondrion is highly efficient. ${ }^{30}$ In other words, if the microvascular $\mathrm{PO}_{2}$ is much greater than $15 \mathrm{~mm} \mathrm{Hg}$, the intact cell should rarely be hypoxic. By comparison, near-infrared spectrophotometric techniques currently in clinical use measure only relative hemoglobin $\mathrm{So}_{2}$ in the microvascular space, so no inference concerning tissue hypoxia can be drawn. Even with multiwavelength near-infrared spectrophotometry, conversion to $\mathrm{PO}_{2}$ depends on knowing the local $\mathrm{pH}, \mathrm{PCO}_{2}$, temperature, and 2,3-diphosphoglycerate content and on whether oxygen-hemoglobin chemical equilibrium is present. Finally, near-infrared spectrophotometry measures only volume-averaged values for microvascular hemoglobin $\mathrm{So}_{2}$. By contrast, multifrequency phosphorimetry reveals the heterogeneity of absolute $\mathrm{PO}_{2}$ in the sampled tissue, which appears to be a more sensitive measure of local tissue hypoxia. We chose a $\mathrm{PO}_{2}$ limit of $15 \mathrm{~mm} \mathrm{Hg}$ as a marker for hypoxic tissue in the single-frequency measurements. This limit is based on our empirical evidence that normally perfused noninjured tissue shows essentially no signal below $15 \mathrm{~mm}$ with this technique. A more precise hypoxic limit could be established by examining indices of cellular metabolism during RLFP.

The technique of phosphorimetry itself has some important limitations, which should be worked out in future studies. For example, in analyzing injured tissue in which substantial heterogeneity in tissue $\mathrm{Po}_{2}$ is expected, the algorithm calculating average tissue $\mathrm{PO}_{2}$ (as in Figure 3) may "phase lock" on a secondary (lower) peak in the $\mathrm{PO}_{2}$ distribution, resulting in a spuriously low average $\mathrm{PO}_{2}$. Second, the analysis of $\mathrm{PO}_{2}$ distribution suffers from low signalnoise ratio at higher $\mathrm{PO}_{2}$ values (on the order of $100 \mathrm{~mm}$ $\mathrm{Hg}$ ), subjecting the calculated ratio in Figure 6 to some uncertainty. These imperfections may explain discrepancies in the calculated quantities between the two RLFP groups in Figures 3 and 6 . For these reasons we believe that $\mathrm{PO}_{2}$ distribution data should be considered to be only qualitative for the present.

This study has several additional limitations, which suggest future studies. First, by attempting to mimic the clinical technique of regional perfusion (into the right carotid and right subclavian arteries), we did not rigorously study isolated cerebral perfusion and metabolism under conditions of constant flow. This study would logically follow our preliminary analysis of tissue $\mathrm{Po}_{2}$. We also suggest a study of RLFP with $\mathrm{pH}$-stat management, with or without $\alpha$-receptor blockade. Additionally, we perfused both carotid arteries in our model, as opposed to the clinical situation in which only the right carotid artery is perfused and the left carotid artery is occluded. In a future study the left carotid artery could be occluded in this porcine model. Finally, the addition in future studies of histologic analyses of end-organ injury would help to clarify the consequences of the metabolic and hemodynamic phenomena that we observed in this study.

Second, we did not rigorously prove that RLFP at the higher flow $(40 \mathrm{~mL} /[\mathrm{kg} \times \mathrm{min}])$ caused the clinical consequences that we observed. The pathophysiology of so-called "hyperperfusion injury" with deep hypothermia is not wellunderstood and requires a detailed study of cerebrovascular endothelial cell function under conditions of excessive flow, which we did not perform in this study. Third, neither others nor we have shown that RLFP at any flow rate improves neurodevelopmental outcome relative to DHCA. An analysis of brain histology, neurologic function, and ultimately long-term neurodevelopment are necessary before one can assert the superiority of one strategy to the other.

\section{Conclusions}

In this neonatal porcine model of RLFP, a flow rate of 40 $\mathrm{mL} /(\mathrm{kg} \times \mathrm{min})$ maintained pre-CPB values of cortical tissue $\mathrm{Po}_{2}$ but resulted in poorer post-CPB recovery. A flow rate of $20 \mathrm{~mL} /(\mathrm{kg} \times \mathrm{min})$ resulted in a lower cortical $\mathrm{Po}_{2}$ but better post-CPB recovery. Neither flow rate adequately oxygenated peripheral organs during regional perfusion. All groups displayed persistent areas of very low $\mathrm{PO}_{2}$ within the sampled cortical tissue after $\mathrm{CPB}$. The technique of oxygen phosphorimetry provides a promising method of assessing absolute tissue $\mathrm{PO}_{2}$ in experimental studies of organ perfusion during cardiac surgery.

\section{References}

1. Asou T, Kado H, Imoto Y, Shiokawa Y, Tominaga R, Kawachi Y, et al. Selective perfusion technique during aortic arch repair in neonates. Ann Thorac Surg. 1996;61:1546-8.

2. McElhinney DB, Reddy VM, Silverman NH, Hanley FL. Modified Damus-Kaye-Stansel procedure for single ventricle, subaortic stenosis, and arch obstruction in neonates and infants: midterm results and techniques for avoiding circulatory arrest. J Thorac Cardiovasc Surg. 1997; 114:718-26.

3. Imoto Y, Kado H, Shiokawa Y, Fukae K, Yasui H. Norwood procedure without circulatory arrest. Ann Thorac Surg. 1999;68:559-61. 
4. Pigula FA, Siewers RD, Nemoto EM. Region perfusion of the brain during neonatal aortic arch reconstruction. J Thorac Cardiovasc Surg. 1999;117:1023-4.

5. Tchervenkov CI, Korkola SJ, Shum-Tim D, Calartitis C, Laliberte E, Reyes T, et al. Neonatal aortic arch reconstruction avoiding circulatory arrest and direct arch vessel cannulation. Ann Thorac Surg. 2001;72:1615-20.

6. Vanderkooi JM, Maniara G, Green TJ, Wilson DF. An optical method for measurement of dioxygen concentration based upon quenching of phosphorescence. J Biol Chem. 1987;262:5476-82.

7. Vinogradov SA, Lo LW, Wilson DF. Dendritic polyglutamic porphyrins: probing porphyrin protection by oxygen-dependent quenching of phosphorescence. Chem Eur J. 1999;5:1338-47.

8. Vinogradov SA, Fernandez-Searra MA, Dugan BW, Wilson DF. Frequency domain instrument for measuring phosphorescence lifetime distributions in heterogeneous samples. Rev Sci Inst. 2001;72:3396-406.

9. Vinogradov SA, Lo LW, Jenkins WT, Evans SM, Koch C, Wilson DF. Noninvasive imaging of the distribution in oxygen in tissue in vivo using near-infrared phosphors. Biophys J. 1996;70:1609-17.

10. Buerk DG, Tsai AG, Intaglietta $\mathrm{M}$, Johnson PC. Comparing tissue $\mathrm{PO}_{2}$ measurements by recessed microelectrode and phosphorescence quenching. Adv Exp Med Biol. 1998;454:367-74.

11. Dewhirst MW, Ong ET, Braun RD, Smith B, Klitzman B, Evens SM, et al. Quantification of longitudinal tissue $\mathrm{pO}_{2}$ gradients in window chamber tumours: impact on tumour hypoxia. Br J Cancer. 1999;79: 1717-22.

12. Vinogradov SA, Wilson DF. Recursive maximum entropy algorithm and its application to the luminescence lifetime distribution recovery. J Appl Spec. 2000;54:849-55.

13. Vinogradov SA, Wilson DF. Phosphorescence lifetime analysis with a quadratic programming algorithm for determining quencher distributions in heterogeneous systems. Biophys J. 1994;57:2048-59.

14. Watanabe T, Oshirkiri N, Kiyoshige I, Kuraoka S, Minowa T, Hosaka J, et al. Optimal blood flow for cooled brain at 20 degrees C. Ann Thorac Surg. 1999;68:864-9.

15. Pigula FA, Nemoto EM, Griffith BP, Siewers RD. Regional low-flow perfusion provides cerebral circulatory support during neonatal aortic arch reconstruction. J Thorac Cardiovasc Surg. 2000;119:331-9.

16. Tanaka H, Kazui T, Satao H, Inoue N, Yamada O, Komatsu S. Experimental study on the optimum flow rate and pressure for selective cerebral perfusion. Ann Thorac Surg. 1995;59:651-7.

17. Swain JA, McDonald TJ, Griffith PK, Balaban RS, Clark RE, Ceckler $\mathrm{T}$. Low flow hypothermic cardiopulmonary bypass protects the brain. J Thorac Cardiovasc Surg. 1991;102:76-84.

18. Tanaka J, Shiki K, Asou T, Yasui H, Tokunaga K. Cerebral autoregulation during deep hypothermic nonpulsatile cardiopulmonary bypass with selective cerebral perfusion in dogs. J Thorac Cardiovasc Surg. 1988;95:124-32

19. Greeley WJ, Kern FI, Ungerleider RM, Boyd JL, Quill T, Smith LR, et al. The effect of hypothermic cardiopulmonary bypass and total circulatory arrest on cerebral metabolism in neonates, infants, and children. J Thorac Cardiovasc Surg. 1991;101:783-94.

20. O'Hare B, Bissonnette B, Bohn D, Cox P, Williams W. Persistent low cerebral blood flow velocity following profound hypothermic circulatory arrest in infants. Can J Anaesth. 1995;42:964-71.

21. O'Rourke MM, Nork KM, Kurth CD. Altered brain oxygen extraction with hypoxia and hypotension following deep hypothermic circulatory arrest. Acta Neurochir Suppl (Wien). 1997;70:78-9.

22. Pesonen EJ, Peltola KI, Korpela RE, Sairanen HI, Leijala MA, Raivio $\mathrm{KO}$, et al. Delayed impairment of cerebral oxygenation after deep hypothermic circulatory arrest in children. Ann Thorac Surg. 1999; 67:1765-70.

23. Schears G, Shen J, Creed J, Zaitseva T, Wilson DF, Greeley WJ, et al. Brain oxygenation during cardiopulmonary bypass and circulatory arrest. Adv Exp Med Biol. 2003;510:325-30.

24. Pigula FA, Gandhi SK, Siewers RD, Davis PJ, Webber SA, Nemoto EM Regional low-flow perfusion provides somatic circulatory support during neonatal aortic arch surgery. Ann Thorac Surg. 2001;72:401-7.

25. Kurth CD, O'Rourke MM, O'Hara IB. Comparison of pH-stat and alpha-stat cardiopulmonary bypass on cerebral oxygenation and blood flow in relation to hypothermic circulatory arrest in piglets. Anesthesiology. 1998;89:110-8.

26. Kurth CD, O'Rourke MM, O'Hara IB, Uher B. Brain cooling efficiency with $\mathrm{pH}$-stat and alpha-stat cardiopulmonary bypass in newborn pigs. Circulation. 1997;96(9 Suppl):II358-63.

27. Hiramatsu T, Miura T, Forbess JM, Du Plessis A, Aoki M, Walter G, et al. $\mathrm{pH}$ strategies and cerebral energetics before and after circulatory arrest. J Thorac Cardiovasc Surg. 1995;110:948-57.

28. DuPlessis AJ, Jonas RA, Wypij D, Hickey PR, Riviello J, Wessel DL, et al. Perioperative effects of alpha stat versus $\mathrm{pH}$ stat strategies for deep hypothermic cardiopulmonary bypass in infants. J Thorac Cardiovasc Surg. 1997;114:991-1001.

29. Priestly MA, Golden JA, O'Hara IB, McCann J, Kurth CD. Comparison of neurologic outcome after deep hypothermic circulatory arrest with alpha-stat and $\mathrm{pH}$-stat cardiopulmonary bypass in newborn pigs. J Thorac Cardiovasc Surg. 2001;121:336-43.

30. Sharan M, Jones MD, Koehler RC, Traystman RJ, Popel AS. A compartmental model for oxygen transport in brain microcirculation. Ann Biomed Eng. 1989;17:13-38.

\section{Discussion}

Dr Davis C. Drinkwater (Nashville, Tenn). That was a lovely article on a new technique that may well advance the science a bit. As you suggested before in your comments, we do not know a lot about this. Am I inferring correctly that more flow, especially during hypothermia, is not better, and that more flow may in fact damage the endothelium? Do you have any histologic data from these studies to demonstrate a difference between the two groups to reflect either vascular or tissue injury?

Dr DeCampli. We are following this study up with a study that looks more closely at the histologic aspects. That is a very good point. You will see here and there in the literature this referred to as "hyperperfusion injury." That is an extremely vague expression, and I think that we have not adequately investigated the phenomenon histologically, both at the neuronal level and at the vascular endothelial level. We intend to do that, and we hope that others will also do so.

Dr Vaughn A. Starnes (Los Angeles, Calif). This was an elegant study, but the model is pretty harsh. With 90 minutes of DHCA, as I guess you have elucidated, none of those animals survived. I do not see any data on them in your results section. And is it not true that it is a little tough to know exactly what you are trying to tell us here, extrapolating this model to a clinical situation? If we had looked at this model for 45 minutes, what do you think those data would have looked like?

Dr DeCampli. That is a very good question. We had some pilot studies in our laboratory. Some of these were carried out with other end points intended by Dr. Bill Gaynor and his team. When we used circulatory arrest periods of 60 minutes or less, we found that we were lacking sensitivity both in our histologic analysis of the brain and in our clinical recovery studies. We have done those studies of chronic recovery, not with the purpose of looking at selective cerebral perfusion but instead looking at things like the effect of modified ultrafiltration, and in those studies we desensitized the experiment because the pigs actually do quite well if the circulatory arrest period was under 60 minutes. So we found empirically that we had to go longer than 60 minutes, and we chose 90 minutes here. It is a bit harsh, and in reality, when we go into our chronic recovery studies more, which we intend to do, we are probably going to settle on a somewhat shorter duration. Incidentally, 18 of 21 animals survived to the pre-set time of termination. None of the 3 deaths was attributable to the duration of DHCA. 